\title{
COMMENTS
}

\section{STRONG ECONOMIC DEVELOPMENT WITHOUT JUDICIAL INDEPENDENCE IN CHINA: A REVIEW}

\author{
MOHAMMAD SAIFUL ISLAM, \\ International Islamic University Chittagong (Kumira, Bangladesh) \\ $\mathrm{XU} X \mathrm{XIN}$ \\ School of Law, Beijing Institute of Technology (Beijing, China)
}

https://doi.org/10.21684/2412-2343-2020-7-1-148-177

Over the last four decades, China has sustained extraordinary economic development despite Western assertions of under-constructed economic markets and the lack of an independent adjudicative process. The purpose of this paper is to set out the context of China's judicial independence and high economic development scenario in the global economy. The paper aims to establish that vast economic expansion is possible without the conventional concept of an independent judiciary in which China provides an important example for the world. The study is mainly qualitative in nature and takes the analytical approach. The data and statistics have been collected from sources of the World Bank, IMF, WTO, UNCTAD, The World Factbook of the CIA, and the Chinese National Bureau of Statistics. The content analysis references the Chinese Constitution and judges law, reports of the Supreme People's Court, books, journal articles, newspaper articles, media reports, and internet documents. The findings of the study are that China preserves "adjudicative independence" as a unique feature instead of embracing the Western concept of judicial independence that promotes the confidence of investors to make more investments. Additionally, the initiatives of "Made in China" and "One Belt, One Road" attach new wings to China's emergence as the world's crucial economic power. The article concludes that China's experience provides a lesson for policymakers and economists of other developing or transitional countries struggling with weak legal and court systems, and emerging financial markets. The study strengthens the flourishing literature on the connection between judicial independence and economic development. 
Keywords: economic development; adjudicative independence; judicial reform; financial reform; corruption.

Recommended citation: Mohammad Saiful Islam \& Xu Xin, Strong Economic Development Without Judicial Independence in China: A Review, 7(1) BRICS Law Journal 128-177 (2020).

\section{Introduction}

As an obligatory branch of the state, the judiciary performs the core function of resolving disputes between parties. It explains and interprets the accurate meaning of the law, and it protects constitutionalism in respect of a matter relating to a written constitution through its exercise of the power of judicial review. Alexander Hamilton stated,

No legislative act ... contrary to the constitution, can be valid.'

The interpretation of the law is a tricky business that belongs to the jurisdiction of the judicial authority. In other words, it has broad discretion to make law in the absence of vibrant indications of congressional legislation. Furthermore, the judiciary can play the healthy role of shaping a nondiscriminatory society through confirming fair justice, safeguarding citizens' rights, imposing a penalty on offenders, and ensuring the safety and security of innocent people from harm. The competent judiciary is a check on the corruption of the executive, bureaucrats, the judiciary itself, corporations, and is an institution whose actions are a crucial factor in maintaining economic growth and poverty reduction. Thus, the independence of the judiciary is essential if it is to perform all of its functions relating to the administration of justice properly. The concept of judicial independence, or the independent judiciary, was invented in Europe and underwent further development in the United States by the framers of the U.S. Constitution. ${ }^{2}$ The U.S. concept is based on the political theory of separation of powers and checks and balances among the governmental organs so as to restrain them from oppressive abuses of their authority. The primary and core feature of an independent judiciary is the maintenance of the judiciary as a separate institution in which one arbitrator or judge can adjudicate disputes neutrally and impartially. ${ }^{3}$

Alexander Hamilton, Federalist No. 78 in Alexander Hamilton et al., The Federalist Papers 235, 237 (New York: Palgrave Macmillan, 2009).

2 For a deeper understanding of the development of judicial independence as conceived in the United States, see Hamilton et al. 2009.

3 James L. Gibson, "New-Style" Judicial Campaigns and the Legitimacy of State High Courts, 71(4) Journal of Politics 1285 (2009). 
The literature on development policy has established the impartial judicial system as a mode of economic development. The importance of an independent judiciary to enhance investment, protect rights, and strengthen democracy is emphasized by international institutions of development funding, including the World Bank, the International Monetary Fund (IMF), and the Inter-American Development Bank. ${ }^{4}$ Feld and Voigt contend that the degree of judicial independence is associated with economic development. ${ }^{5}$ The world's largest financial institution (the World Bank) promotes an independent judiciary as a means of gaining more economic growth and control of corruption. ${ }^{6}$ The absence of well-functioning legal and court systems, and the existence of corruption, are limitations to economic growth and sustainability of development.? A well-performing and robust court system is linked with the faster growth of both small and large businesses in the economy. ${ }^{8}$ One World Bank report stated that larger and more efficient firms found with better court systems that reduce the risk of firms show a willingness towards more investment. ${ }^{9}$ Hence, an independent judiciary has a potentially crucial role in advancing a country's economic growth.

Yet, in China, economic development has occurred seemingly as a "miracle" and in spite of the conventional independent judiciary promoted with devotion by Western legal scholarship and economists. China is an extraordinary instance of an economy in respect of enhancing economic development within a short period of time that is already dignified as one of the fastest growing economies and which has attained the rank of the second largest economy in the world based on real gross domestic product (GDP). Many economists predict that China will be the largest economy within a few years, thus surpassing the U.S. economy. In fact, measured by purchasing power parity (PPP) China has already overtaken the U.S. economy and possesses the

4 Rebecca B. Chavez, The Rule of Law and Courts in Democratizing Regimes in The Oxford Handbook of Law and Politics 63 (K.E. Whittington et al. (eds.), New York: Oxford University Press, 2008).

5 Lars P. Feld \& Stefan Voigt, Making Judges Independent - Some Proposals Regarding the Judiciary, Center for Economic Studies and Ifo Institute (CESifo), Working Paper No. 1260 (February 2004) (Dec. 20, 2019), available at https://papers.ssrn.com/sol3/papers.cfm?abstract_id=597721.

6 For more authorization see, among others, the report, The World Bank, Helping Countries Combat Corruption: The Role of the World Bank (1997) (Dec. 20, 2019), available at http://www1.worldbank.org/ publicsector/anticorrupt/corruptn/corrptn.pdf; The World Bank, Building Institutions for Markets (2002) (Dec. 20, 2019), available at http://documents.worldbank.org/curated/en/850161468336075630/pdf /228250WDR00PUB0ons0forOmarkets02002.pdf; World Development Report 2005: A Better Investment Climate for Everyone (New York: The World Bank and Oxford University Press, 2004).

7 The World Bank, Initiatives in Justice Reform 1992-2012 (2012) (Dec. 20, 2019), available at http:// documents.worldbank.org/curated/en/575811468175154113/pdf/707290WPOFull000Box370050B OOPUBLIC0.pdf.

8 Roumeen Islam, Institutional Reform and the Judiciary: Which Way Forward?, World Bank Policy Research Working Paper 3134 (September 2003), at 7-8 (Dec. 20, 2019), available at http://documents.worldbank. org/curated/en/320271468779353185/pdf/WPS3134.pdf.

9 World Development Report 2005, supra note 6, at 86. 
rank of the largest economy in the world. The World Bank has stated that China is "the fastest sustained expansion by a major economy in history."10

This study reveals the factors behind China's unprecedented economic growth despite the Western contention of its having weak legal institutions, a lack of judicial independence, and underdeveloped economic sectors.

\section{Judicial Independence and China's Position}

\subsection{Conventional Concept of Judicial Independence}

Judicial independence is one of the fundamental values and central principles of the administration of justice. ${ }^{11}$ However, the concept of judicial independence ${ }^{12}$ is a multifaceted idea, ${ }^{13}$ and "one of the least understood concepts."14 ${ }^{14}$ The delineation of judicial independence is hardly exactly the same everywhere since it is a matter of a mixture of many elements, such as the constitutional provision, legislative enactments, the selection method of judges through a merit basis, or open-ended executive selection within the socio-political culture. It differs from country to a country, dependent on the legal system, the governmental system, traditions and political estimations. ${ }^{15}$ Conventionally, judicial independence refers to the freedom of judges to execute judicial functions without any explicit or implicit interference from the outside, chiefly from the executive branch of the government, and the independence that judges have from internal influences of senior colleagues. It requires that the judiciary should not be subject to regulation by the executive branch of government, and that judges should enjoy "protection from any threats,

10 The World Bank, The World Bank in China: Overview (2019) (Dec. 20, 2019), available at https://www. worldbank.org/en/country/china/overview.

11 Shimon Shetreet, Creating a Culture of Judicial Independence: The Practical Challenge and the Conceptual and Constitutional Infrastructure in The Culture of Judicial Independence: Conceptual Foundations and Practical Challenges 15, 18 (S. Shetreet \& C. Forsyth (eds.), Leiden: Martinus Nijhoff Publisher, 2012); Mohammad Saiful Islam, Independent Judiciary: Nature and Facets from the International Context, 6(2) International Journal of Ethics in Social Sciences 15, 17 (2018).

12 For more on the fundamental concept and nature of an independent judiciary, see Saiful Islam 2018.

13 Shimon Shetreet, Judicial Independence and Accountability: Core Values in Liberal Democracies in Judiciaries in Comparative Perspective 3 (H.P. Lee (ed.), New York: Cambridge University Press, 2011); Judicial Independence: The Contemporary Debate 6 (S. Shetreet \& J. Deschênes (eds.), Dordrecht; Boston; Lancaster: Martinus Nijhoff Publishers, 1985); Zhao Yanrong, The Way to Understand the Nature and Extent of Judicial Independence in China, 6(01) Asian Journal of Law and Society 131 (2018) (Dec. 20, 2019), available at https://www.semanticscholar.org/paper/The-Way-to-Understand-the-Nature-andExtent-of-in-Zhao/80d21d6658719c2ad1fa2bd91b1dd59fce608d92.

14 Christopher M. Larkins, Judicial Independence and Democratization: A Theoretical and Conceptual Analysis, 44(4) American Journal of Comparative Law 605, 607 (1996).

15 Lord Hailsham, The Independence of the Judicial Process, 13(1) Israel Law Review 1 (1978); Eli M. Salzberger, A Positive Analysis of the Doctrine of Separation of Powers, or: Why Do We Have an Independent Judiciary?, 13(4) International Review of Law Economics 349, 350 (1993). 
interference, or manipulation which may either force them to unjustly favor the government or subject themselves to a penalty for not doing so."16

In other words, judicial independence denotes that judges are free from any influences in reaching a decision in the case before them, neither influences by the political branches of government nor influences by judicial colleagues, and that they are free from personal worry with regard to their performance of their official judicial obligations. It necessitates that

a judge adjudicates without fear or favor, even in the face of a contrary view widely held by others, whether judicial colleagues, government, the public, the media, or interest groups. ${ }^{17}$

The ideal and most favorable concept of judicial independence brings to mind the U.S. practice of judicial independence. In the United States, the independence of the judiciary maintains both the independence of individual judges and the independence of the judiciary as an autonomous institution that is separate from the executive and legislative branches. It is based on the political theory of separation of powers and checks and balances among the governmental organs so as to restrain them from oppressive abuses of their authority. Hence, the conventional concept of judicial independence maintains two substantial elements: the independence of individual judges, or the adjudicative independence of individual judges, and the institutional independence of the judiciary. ${ }^{18}$

\subsection{General Depiction of China's Judicial Independence}

The president of the Supreme People's Court Zhou Qiang has stated that China would absolutely say no to the separation of powers, constitutional democracy, and judicial independence because he considers these are all Western ideals that are damaging to the Chinese Communist Party's (CCP) rule. ${ }^{19}$ China's judiciary has consistently been depicted as not being independent ${ }^{20}$ as being entirely subservient

16 Larkins 1996, at 608.

17 Why Is Judicial Independence Important to You?, Canadian Judicial Council (May 2016) (Dec. 20, 2019), available at https://www.bccourts.ca/documents/Why_is_Judicial_Independence_Important_to_You.pdf.

18 Shetreet 2011, at 15; Sarkar Ali Akkas, Judicial Independence and Accountability: A Comparative Study of Contemporary Bangladesh Experience, Doctor of Philosophy Thesis, Faculty of Law, University of Wollongong (2002), at 14 (Dec. 20, 2019), available at https://ro.uow.edu.au/theses/1856/; Shimon Shetreet, Judicial Independence: New Conceptual Dimensions and Contemporary Challenges in Judicial Independence: The Contemporary Debate 590, 598 (S. Shetreet \& J. Deschênes (eds.), Dordrecht; Boston; Lancaster: Martinus Nijhoff Publishers, 1985); John Ferejohn, Independent Judges, Dependent Judiciary: Explaining Judicial Independence, 72(2-3) Southern California Law Review 353, 355 (1999).

19 Xin He, The Politics of Courts in China, 2(2) China Law and Society Review 129, 131 (2017).

20 Veron Mei-Ying Hung, China's WTO Commitment on Independent Judicial Review: Impact on Legal and Political Reform, 52(1) American Journal of Comparative Law 77 (2004); Pierre Landry, The Institutional Diffusion of Courts in China: Evidence from Survey Data in Rule by Law: The Politics of Courts in Authoritarian Regimes 207, 209 (T. Ginsburg \& T. Moustafa (eds.), New York: Cambridge University Press, 2008). 
to the government's rule by one party (the CCP) and without judicial independence and the separation of powers. ${ }^{21}$ The root of this criticism is that the state appoints judges from among the members of the Party, who are checked by the Party's section in the judiciary, and who in practice must respond to administrative seniors within local governments. ${ }^{22}$ Similarly, scholars claim that lawyers and social activists connected with judicial institutions are vetted continuously, and information streams are comprehensively controlled. Generally, the action by anyone of initiating a challenge against state actors or going to court to pursue a case remains a highly charged political matter. ${ }^{23}$ All in all, there are intense debates and even completely opposite opinions, instead of consensus, regarding the nature and the extent of China's judicial independence among legal scholars inside and outside China, among Party executives, and even among the people.

\subsection{Communal Insights and the Constitution of China}

There are several approaches ${ }^{24}$ to understanding the nature and the extent of judicial independence in China. Outside these doctrinal approaches, the communal insights towards China's judicial independence are: most of the existing literature perceives judicial independence in China "as stagnant," 25 that it has little judicial independence, ${ }^{26}$ that it does not exist or is vulnerable to influence from a diversity of sources, ${ }^{27}$ that it is not fixed but changes on the basis of court discretion assigned to judges by the $C C{ }^{28}$ Referring to judicial reform, a number of scholars have stated that "the judiciary has become more competent, authoritative, and independent."29 Additionally, an opposite view asserts that China's judicial independence has been

21 Jerome A. Cohen, The Chinese Communist Party and "Judicial Independence": 1949-1959, 82(5) Harvard Law Review 967 (1969); Kenneth W. Dam, The Law-Growth Nexus: The Rule of Law and Economic Development 250 (Washington, D.C.: Brookings Institution Press, 2007).

22 Yi Zhao, The Expansion of Judicial Power in China (New Haven: Yale University Press, 2003).

23 Mary E. Gallagher, Use the Law as Your Weapon! The Rule of Law and Labor Conflict in the PRC in Engaging the Law in China: State, Society, and Possibilities for Justice 54 (N.J. Diamant et al. (eds.), Stanford: Stanford University Press, 2005).

${ }^{24}$ Yanrong has identified three leading schools of thought to understand the nature and the extent of judicial independence in China: The International Best Practice School, China's Special Condition, and the Strategic Interaction School. See Yanrong 2018.

25 Id. at 1.

26 Xin He, Ideology or Reality?: Limited Judicial Independence in Contemporary Rural China, 6(3) Australian Journal of Asian Law 213 (2004).

27 William Fairbairn, An Examination of Judicial Independence in China, 23(4) Journal of Financial Crime 819 (2016).

28 Yanrong 2018.

29 Randall Peerenboom, Judicial Independence in China: Common Myths and Unfounded Assumptions in Judicial Independence in China: Lessons for Global Rule of Law Promotion 69, 87 (R. Peerenboom (ed.), New York: Cambridge University Press, 2009). 
established more than China's necessity. ${ }^{30}$ The Constitution and judges law of China mandate that the courts perform independent adjudication without any interference of any organization or individual. In 1954, the first Constitution specified,

The people's courts adjudicate cases independently, only subject to the law..

Later, in 1982, the Constitution of China stipulated,

The people's courts exercise judicial power independently, in accordance with the provisions of law and not subject to interference by any administrative organ, public organization or individual. ${ }^{32}$

Judges law of the People's Republic of China states,

Judges performing their duties in accordance with law are protected by law and are not to be interfered with by administrative organs, social organizations and individuals. ${ }^{33}$

On the basis of an analysis of Article 126 of the Constitution, some scholars mention that in China the court does enjoy judicial independence, albeit a tiny amount. The arguments on this position are that while Article 126 prohibits interference in court adjudication by public organizations, administrative organs, and individuals, it is not clear whether the CCP is included as an organization, and the article is silent about the People's Congress, and the procuracy. ${ }^{34}$ From this position, it is implied that political influence from some other state organs over the adjudication process can occur. ${ }^{35}$ By comparison of these two provisions (Article 78 of 1954 and Article 126 of 1982) of the Constitution, Chinese scholars conclude that the provision of 1954 was better in the logic that judges were only accountable to the law for its independent adjudication, and Article 126 worsens the matter rather than being a welcome development, and thus it should be revised. ${ }^{36}$ Consequently, the "current

30 司法独立已经实现?! [Has Judicial Independence Been Established?!] (China: China law info, 2010).

31 Constitution of the People's Republic of China (1954), Sec. VI, Art. 78.

32 Constitution of the People's Republic of China (1982), Ch. III, Sec. 7, Art. 126.

33 Judges Law of the People's Republic of China, amended on 23 April 2019, effective on 1 October 2019, Ch. I: General Provision, Art. 7.

34 Lin Feng, The Future of Judicial Independence in China, Centre for Judicial Education and Research, City University of Hong Kong, Working Paper Series No. 2 (May 2016), at 5 (Dec. 20, 2019), available at https://www.cityu.edu.hk/cjer/lib/doc/paper/WK2_The_Future_of_Judicial_Independence_in_ China.pdf; He, China Law and Society Review (2017), at 131.

35 Feng, supra note 34, at 5; He, supra note 34, at 131.

36 Tong Zhiwei, Perfecting the Constitutional Provision on Independent Adjudication and Ancillary Reform, 6 Jianghai Academic Journal 109 (2005). 
Chinese laws demand only limited respect for the principle of judicial independence" for the reason that the law does not explicitly prohibit interventions "by the CCP, from the legislative organs, or from higher courts. ${ }^{137}$

\subsection{Summary of Judicial Independence in China}

In reality, in China's one-party political system and considering China's political estimations, the conventional theory of separation of power is impossible; therefore, it does not exist in China. The conventional concept of separation of powers provides checks and balances between the government branches that control abuses of authority; these are not maintained in China. In China, members of the National People's Congress (NPC) simultaneously possess seats in the Party and in the government, and the members of the NPC naturally include all of the high-ranking officials of the CCP. Also, the NPC supervises the actions of the government, the supreme procuratorate, the supreme court, and the central military commission. Hence, judicial independence in China offers adjudicative independence of individual judges, or an impartial adjudication, not institutional independence of the judiciary. The degree of adjudicative independence is developing and changeable by the extent of judicial discretion delegated by the CCP to judges. However, Larkins considers that,

Judicial independence is not meaningful if the courts cannot exercise it to check the arbitrary or unjust exercise of power by political actors. ${ }^{38}$

The positive side of this matter is that the CCP has been putting into place a variety of judicial reforms over numerous rounds, with the purpose of confirming a more independent, strong, and efficient judiciary. However, scholars claim that all these reform initiatives have to be executed under the CCP's headship, and conventionally they do not permit any matters to undermine the Party's leadership position. ${ }^{39}$

\section{Economic Growth Without Judicial Independence in China}

In China, beginning in 1921, with the founding of the CCP, the law was used as a tool under Marxist-Leninist ideology to rebuild society, suppress class opponents, and administer Party policy. ${ }^{40}$ At that time,

37 Yuwen Li, Judicial Independence in China: An Attainable Principle? (The Hague: Eleven International Publishing, 2013).

38 Larkins 1996, at 611.

39 Peter C.H. Chan, An Uphill Battle: How China's Obsession with Social Stability Is Blocking Judicial Reform, 100(3) Judicature 14 (2016).

40 Jianfu Chen, Chinese Law: Towards an Understanding of Chinese Law, Its Nature, and Development § 3 , 34 (The Hague; Boston: Martinus Nijhoff Publishers, 1999). 
The courts were to serve as instruments for suppressing the enemies of the state rather than protecting individual rights. ${ }^{41}$

In the post-Mao era, the Chinese government took the rule of law to be a dominant component for its legitimation strategy. ${ }^{42}$ As early as 1969 , Jerome A. Cohen commented,

[J]udicial independence can hardly be deemed irrelevant to [the] PRC's future development. ${ }^{43}$

Today, fifty years later, his prediction has been demonstrated to be accurate. ${ }^{44}$ The reality is that for the world community China is perceived as a country without judicial independence and, most of the time, criticized for the factors that influence the process of decision making of judges, particularly the big role played by the government and the influence of the CCP on the judiciary.

\subsection{China's Economic Scenario in Brief}

Despite the hugh question regarding the deficiency of judicial independence in China, and regardless of its weak financial and legal systems, it is one of the fastestgrowing economies. ${ }^{45}$ China is the second-largest country in terms of its economy in the world, and it has shown comparable advancement in various other fields. Additionally, its economy is recognized as one of the most significant to the world economy. ${ }^{46}$ According to the World Bank, from 1979 to 2018 China's real GDP grew at the rate of nearly $10 \%$ a year on average. The World Bank has described China as having "the fastest sustained expansion by a major economy in history." ${ }^{177}$ The U.S. Congressional Research Service (CRS) has noted that China "ranks first in terms of economic size on PPP basis, value-added manufacturing, merchandise trade, and holder of foreign exchange reserves." ${ }^{\prime \prime 8}$ Over the past four decades, China has attained extraordinary economic development that has been described as a miracle. At the end

$41 \quad$ Yanrong 2018.

42 Randall Peerenboom, China's Long March Toward Rule of Law (Cambrige and New York: Cambridge University Press, 2002).

43 Cohen 1969 , at 1005.

44 Feng, supra note 34 , at 1.

45 Franklin Allen et al., Law, Finance, and Economic Growth in China, 77(1) Journal of Financial Economics 57,59 (2005).

46 Dam 2007, at 221, 233.

47 The World Bank in China: Overview, supra note 10.

48 Wayne M. Morrison, China's Economic Rise: History, Trends, Challenges, Implications for the United States, Congressional Research Service, CRS Report RL33534 (August 2014), at 1 (Dec. 20, 2019), available at https://digitalcommons.ilr.cornell.edu/cgi/viewcontent.cgi?article=2323\&context=key_workplace. 
of 2010, China became the second-biggest economy by overtaking Japan, and thus just behind the United States. At that time, Japan's economy was valued at US\$5.474 trillion, and China's economy was nearly $\$ 5.8$ trillion. ${ }^{49}$ In 2018 , China's GDP growth was $6.6 \%$ with nominal GDP of $\$ 13.608$ trillion, $^{50}$ which is an increase of more than $\$ 2$ trillion compared to $2017 . .^{51}$ In 2019, China's economy is expected to grow $6.4 \%$ with a nominal GDP estimate exceeding $\$ 14.5$ trillion. According to the World Economic Outlook (April 2019), China will reach $\$ 14.22$ trillion. The GDP per capita also rose to $\$ 9,770$ in 2018, almost ten times that of $2001(\$ 1,000)$, and which was only $\$ 205$ in $1980 .{ }^{52}$ According to the World Bank data, between 2017 and 2019 the world economy will increase by $\$ 6.5$ trillion. While $17.9 \%$ of this estimated growth relates to the USA (GDP), China is predicted to contribute $35.2 \%$ - almost double that of the USA. ${ }^{53}$

China is the largest exporter and second largest importer in the world. In 2017, China's exports amounted to $\$ 2.41$ trillion. During the five years from 2012 to 2017, China's exports grew at an annualized rate of $2.5 \%$ (from $\$ 2.12$ trillion to $\$ 2.41$ trillion). In 2017, China's imports amounted to $\$ 1.54$ trillion. During the same five-year period China's imports grew at an annualized rate of 1.3\% (from $\$ 1.42$ trillion to $\$ 1.54$ trillion). Moreover, China has been the largest global Foreign Direct Investment (FDI) recipient among developing countries. In 1991, China attracted $\$ 4.37$ billion of FDI, and in 1993 FDI reached $\$ 27.52$ billion. In 2003, China even surpassed the USA when it was ranked the number one FDI recipient among all economies..$^{54}$ In 2014 , China again surpassed the USA when it was ranked the largest FDI recipient among all countries. In 2017 and 2018, China received \$134 billion and \$139 billion, respectively, as the second largest FDI recipient among all countries (Fig. 1). ${ }^{55}$ James Zhan, director of the United Nations Conference on Trade and Development's (UNCTAD) Division on Investment and Enterprise, noted,

49 World Economic Outlook Report (2010).

50 World Bank national accounts data, and OECD National Accounts data files (2018).

51 This growth in GDP is the slowest pace since 1990. Economists had predicted similar results due to the ongoing U.S.-China trade war that depresses the country's exports.

52 World Bank national accounts data, and OECD National Accounts data files (2018). However, China News Agency stated on 21 January 2019 that China's GDP per capita almost exceeded $\$ 10,000$ for the prior year. See China's GDP per capita to exceed \$10,000, People's Daily Online, 23 January 2019 (Dec. 20, 2019), available at http://en.people.cn/n3/2019/0123/c90000-9540867.html.

53 Rob Smith, The World's Biggest Economies in 2018, The World Economic Forum, 18 April 2018 (Dec. 20, 2019), available at https://www.weforum.org/agenda/2018/04/the-worlds-biggest-economies-in-2018/.

54 Li Yang, China's Growth Miracle: Past, Present, and Future, United Nations Research Institute for Social Development (2013), at 9 (Dec. 20, 2019), available at https://www.semanticscholar.org/paper/China-'-sGrowth-Miracle-\%3A-Past-\%2C-Present-\%2C-and-Yang/9de08aecedc40d51843e67adda9d750c4a 40 cc54.

55 UNCTAD, World Investment Report 2019: Special Economic Zones (2019), at 4 (Dec. 20, 2019), available at https://unctad.org/en/pages/PublicationWebflyer.aspx?publicationid=2460. 
The investment flows to China continue to increase despite mounting trade tension, and increasing cost of production.

This statement was delivered at the time of publishing a report on investment trends monitored in October 2018 by UNCTAD. ${ }^{56}$

Figure 1: China's ranking among the largest economies

in 2018

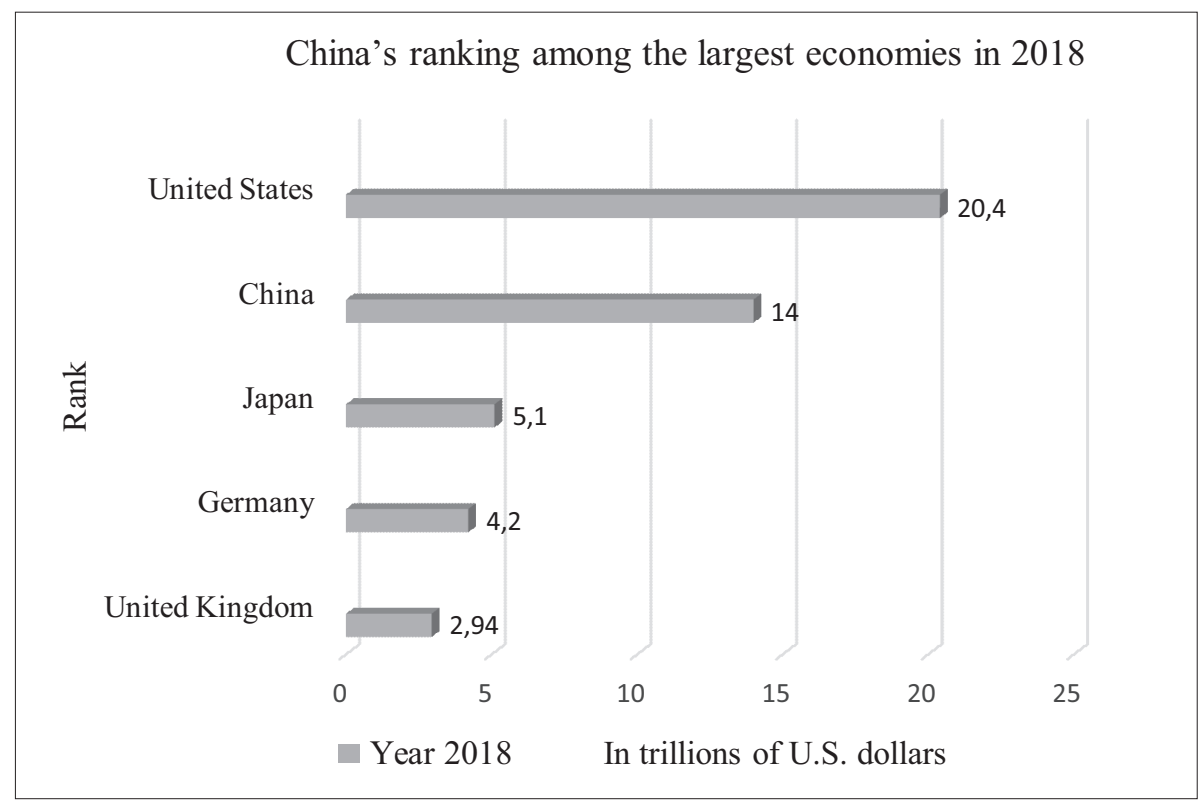

Data source: IMF

These are the world's five largest economies in 2018 based on data from the International Monetary Fund, 2018. In fact, measured by PPP, China is the largest economy in the world ${ }^{57}$ but when measured by the nominal GDP the United States is largest.

56 China Becomes Largest Recipient of FDI in H1, Xinhuanet, 16 October 2018 (Dec. 20, 2019), available at http://www.xinhuanet.com/english/2018-10/16/c_137534827.htm.

57 CIA, The World Factbook 2018 (2018) (Dec. 20, 2019), available at https://www.cia.gov/library/publications/ download/download-2018/index.html. 
Figure 2: China's real GDP growth: 2000-2018

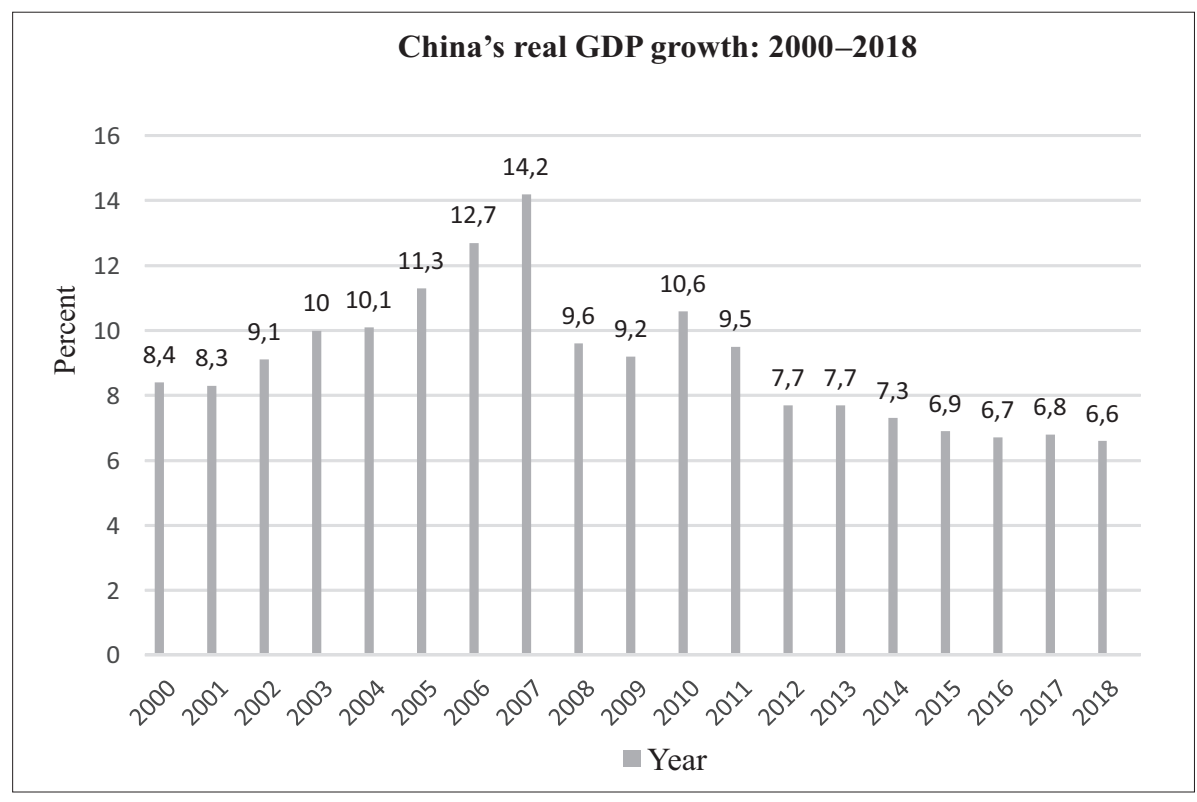

Data source: IMF, and the Chinese National Bureau of Statistics

From 2000 to 2018, China's annual growth in real GDP averaged 9.08\% (Fig. 2). From 2000 to 2007 GDP increased at the, remarkable, average annual rate of $10.51 \%$. From 2008 to 2010 annual GDP growth averaged 9.8\%. Though the rate of annual GDP growth fell for the subsequent six successive years, decreasing from $10.6 \%$ in 2010 to $6.7 \%$ in 2016, it increased to $6.8 \%$ in 2017.

Table 1: China's position as an exporter

\begin{tabular}{|c|c|c|c|c|}
\hline Rank & Country & $\begin{array}{c}\text { Exports Value } \\
(\mathbf{2 0 1 7 )}\end{array}$ & $\begin{array}{c}\text { Exports Value } \\
\mathbf{( 2 0 1 8 )}\end{array}$ & $\begin{array}{c}\text { Annual } \\
\text { \% change }\end{array}$ \\
\hline 1 & China & $\$ 2.263$ trillion & $\$ 2.487$ trillion & $10 \%$ \\
\hline 2 & United States & $\$ 1.547$ trillion & $\$ 1.664$ trillion & $8 \%$ \\
\hline 3 & Germany & $\$ 1.448$ trillion & $\$ 1.561$ trillion & $8 \%$ \\
\hline 4 & Japan & $\$ 698$ billion & $\$ 738$ billion & $6 \%$ \\
\hline 5 & Netherlands & $\$ 652$ billion & $\$ 723$ billion & $11 \%$ \\
\hline
\end{tabular}

Data source: World trade statistical review of the WTO, 2018 and 2019

In 2017, China's exports amounted to $12.8 \%$ of global exports. In 2018 , they amounted to the same percentage. China's exports in 2018 registered an increase of 
approximately 10\% over 2017, and this resulted in China being the second highest in the given countries (the Netherlands had an increase of $11 \%$ ) (Table 1)..$^{58}$

Figure 3: Value of China's exports

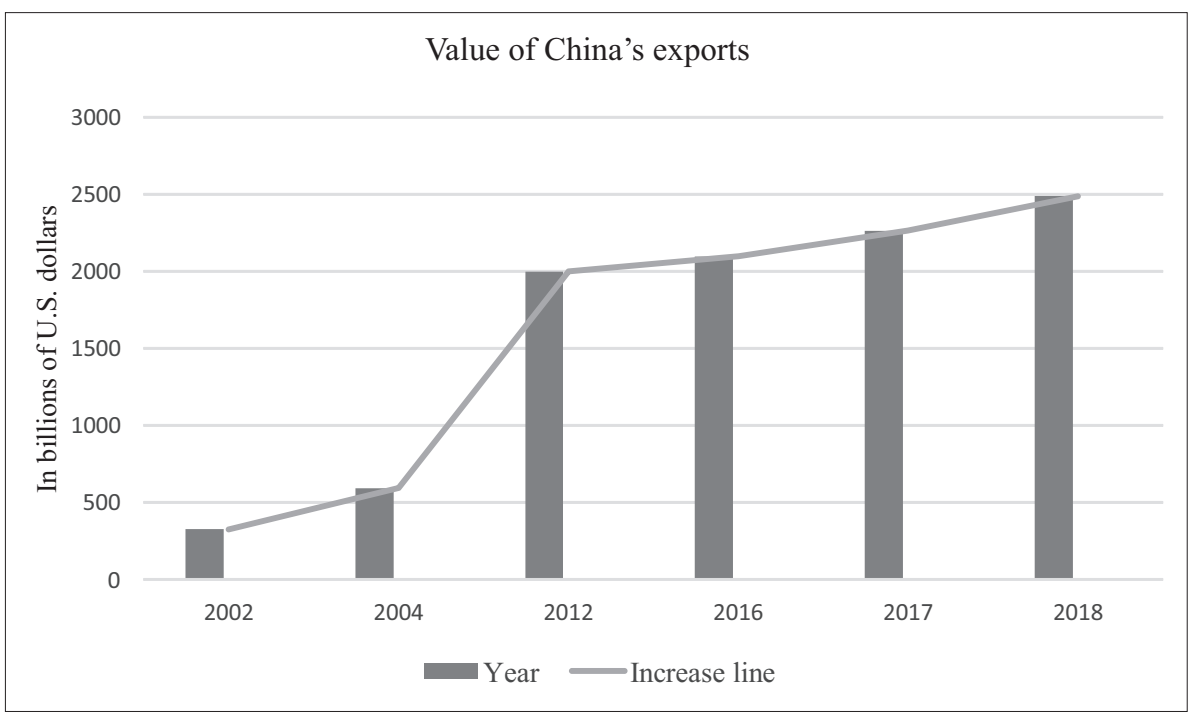

Data source: World trade statistical review of the WTO

The value of the goods exported by China has grown immensely over the years (Fig. 3). In 2002, the value of China's exports was about $\$ 327$ billion. In 2004, the value of its exports was over 35\% larger. In 2012, for the first time the value of China's exports exceeded $\$ 2$ trillion. In 2016, China contributed $13.2 \%$ of total global exports. China's exports in 2017 were 8\% larger than its exports in 2016.

Table 2: China's position as an importer

\begin{tabular}{|c|c|c|c|c|}
\hline Rank & Country & $\begin{array}{c}\text { Imports Value } \\
(\mathbf{2 0 1 7 )}\end{array}$ & $\begin{array}{c}\text { Imports Value } \\
(\mathbf{2 0 1 8 )}\end{array}$ & $\begin{array}{c}\text { Annual } \\
\text { \% change }\end{array}$ \\
\hline 1 & United States & $\$ 2.410$ trillion & $\$ 2.614$ trillion & $9 \%$ \\
\hline 2 & China & $\$ 1.842$ trillion & $\$ 2.136$ trillion & $16 \%$ \\
\hline 3 & Germany & $\$ 1.167$ trillion & $\$ 1.286$ trillion & $11 \%$ \\
\hline
\end{tabular}

58 WTO, World Trade Statistical Review 2018 (2018), at 124 (Dec. 20, 2019), available at https://www.wto.org/ english/res_e/statis_e/wts2018_e/wts18_toc_e.htm;WTO,World Trade Statistical Review 2019 (2019), at 100 (Dec. 20, 2019), available at https://www.wto.org/english/res_e/statis_e/wts2019_e/wts19_toc_e.htm. 


\begin{tabular}{|c|c|c|c|c|}
\hline 4 & Japan & $\$ 672$ billion & $\$ 749$ billion & $11 \%$ \\
\hline 5 & United Kingdom & $\$ 644$ billion & $\$ 674$ billion & $5 \%$ \\
\hline
\end{tabular}

Data source: World trade statistical review of the WTO, 2018 and 2019

In 2017, China's imports amounted to $10.2 \%$ of global imports, and in $201810.8 \%$. China's imports increased by $16 \%$ from 2017 to 2018 , which was the largest increase in the countries under review (Table 2$)^{59}$

Figure 4: China's ranking - amount of FDI in 2017 and 2018

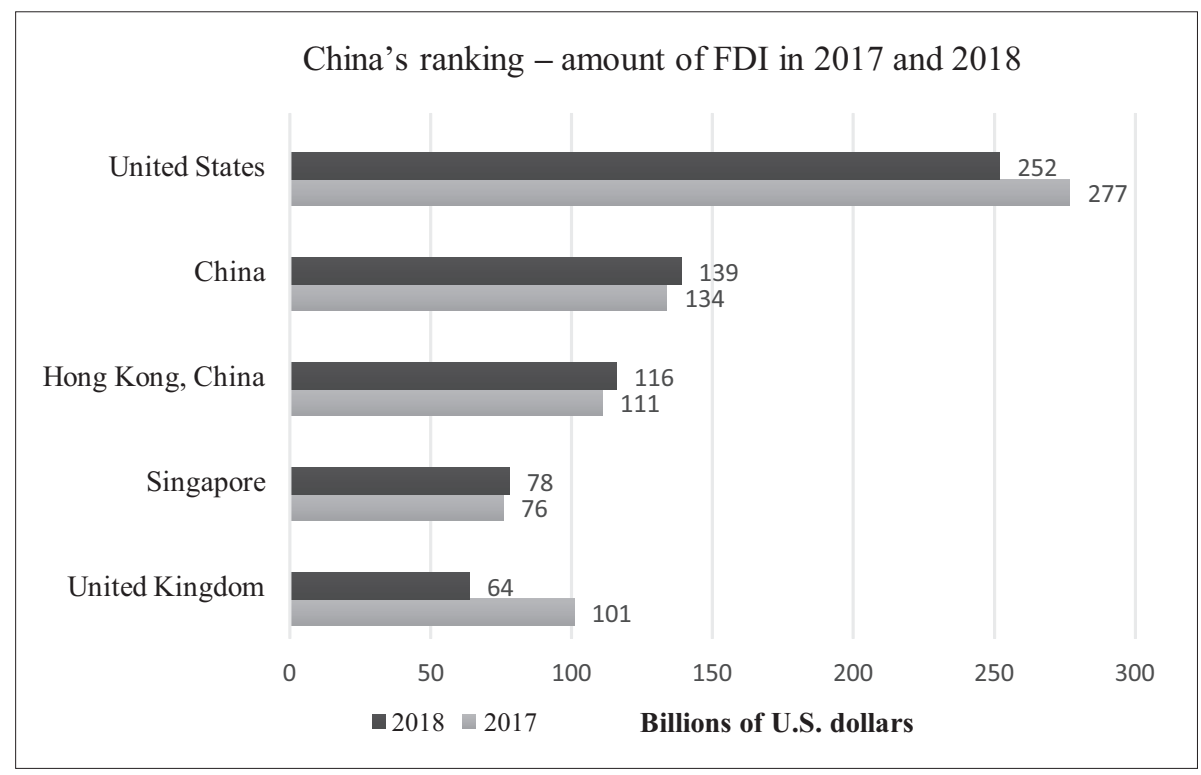

Data source: World Investment Report 2019 of UNCTAD

In 2017 and 2018, China remained the second largest FDI recipient among all economies. In 2018, China attracted a record $\$ 139$ billion worth of FDI, which was an increase of 3\% over 2017.

59 World Trade Statistical Review 2018, supra note 58, at 124; World Trade Statistical Review 2019, supra note 58 , at 100 . 
Figure 5: China's FDI inflows

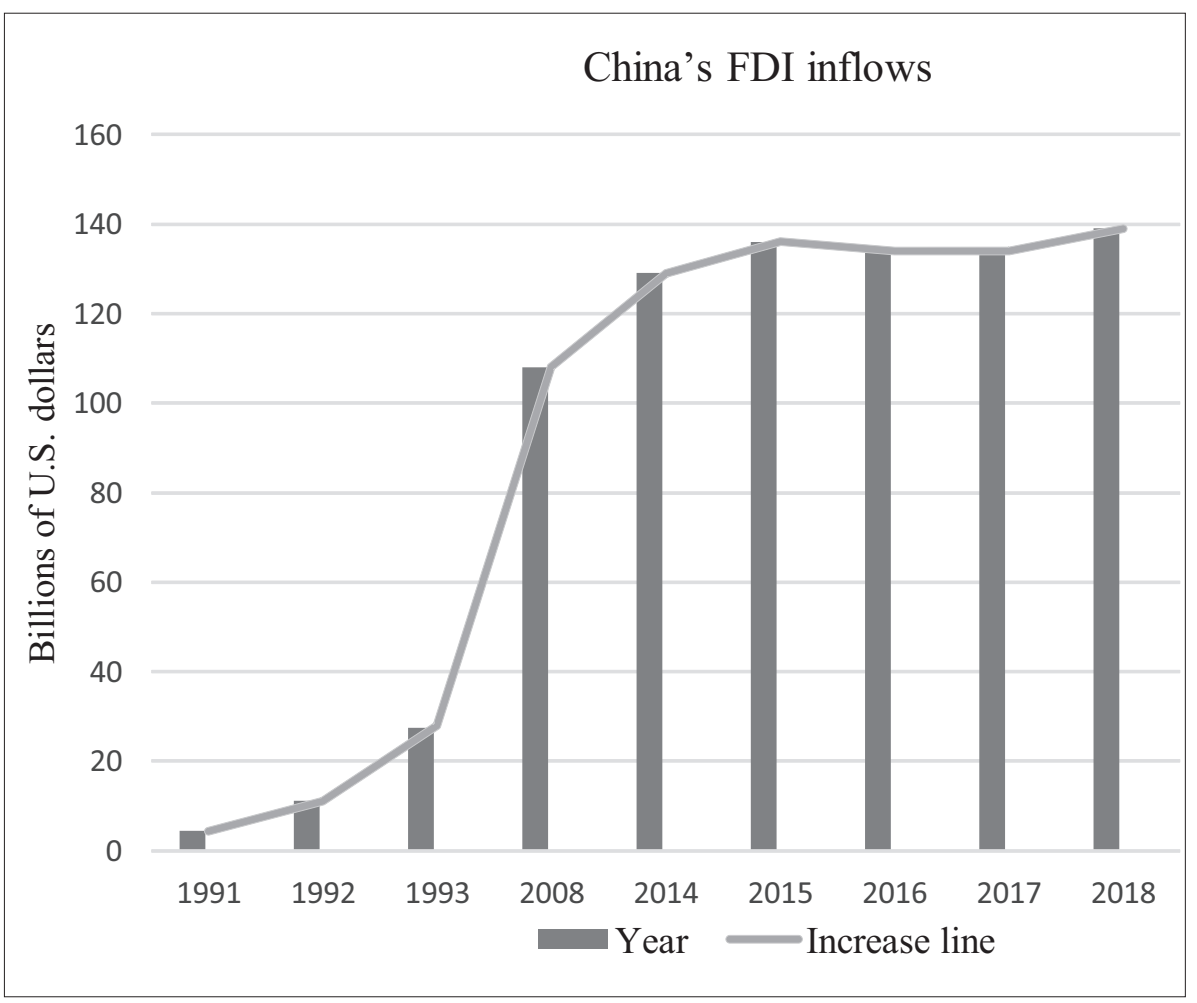

Data source: World Investment Report of UNCTAD

In 1991, China's FDI was a dignified 1.15\% of GDP; by 1993 it had risen to $6.25 \%$ of GDP. Every year thereafter saw a significant increase in this percentage. In 2015 and 2016, China was ranked as the third-largest recipient of FDI among all countries. And just one year earlier, in 2014, China attracted $\$ 129$ billion of FDI and attained the ranking of the number one receiver among all economies by surpassing the United States (\$107 billion) (Fig. 5).

China's economic miracle can be regarded as the most impressive, lasting, and complex in standings of institutional reforms and restraint conditions in the history of economic growth, which has been recognized by prestigious economists and organizations across the globe. ${ }^{60}$ Some economic pundits envisage that before the end of this second decade of the century China's economy will exceed the size of the U.S. economy. ${ }^{61}$ This, in fact, is the case, when measured on the basis of PPP, notwithstanding

60 Yang, supra note 54, at 3.

61 Allen et al. 2005, at 59. 
the economic and trade actions (e.g. tariffs) imposed on China by the U.S. in recent years, to the detriment of China's economic growth (Table 3). ${ }^{62}$

Table 3: China's ranking on the basis of PPP

\begin{tabular}{|c|c|c|c|c|}
\hline Rank & Country & $\begin{array}{c}\text { GDP (PPP) } \\
\text { in } \mathbf{2 0 1 7}\end{array}$ & $\begin{array}{c}\text { GDP (PPP) } \\
\text { in 2018 }\end{array}$ & Share \% \\
\hline 1 & China & \$23.2 trillion & \$25.3 trillion & 18.7 \\
\hline 2 & United States & \$19.4 trillion & \$20.5 trillion & 15.2 \\
\hline 3 & India & \$9.4 trillion & \$10.4 trillion & 7.69 \\
\hline 4 & Japan & \$5.4 trillion & \$5.6 trillion & 4.16 \\
\hline 5 & Germany & \$4.1 trillion & \$4.3 trillion & 3.24 \\
\hline
\end{tabular}

Data source: International Monetary Fund, World Economic Outlook (October 2018)

Economists, legal scholars, and international financial institutions agree that an independent judicial system is necessary to enhance and sustain economic development. In this study, the authors also take a similar standpoint. However, the level of judicial independence in China and its high economic growth clearly raise several questions as to the interested people in this fact. For example, How is China's speed of economic growth suitable to its degree of judicial independence? Does the simultaneity of great economic growth and little judicial independence indicate that an independent judiciary is not important to economic development in the end? A number of scholars have concluded that,

China is an important counterexample to the findings in the law, institutions, finance, and growth literature: neither its legal nor financial system is well developed by existing standards, yet it has one of the fastestgrowing economies. ${ }^{63}$

62 The advent of China as a major and influential economic power in the world raised anxiety among many U.S. policymakers. Nevertheless, at present China is the largest merchandise trading partner of the United States, the biggest source of imports, and the third-largest U.S. export market. As stated by U.S. trade data, in 2017 the total commerce between the two countries produced an estimated $\$ 634$ billion (which had been only $\$ 5$ billion in 1980). U.S. policymakers claim that China exercises unfair trade practices that threaten "American jobs, wages, and living standards." See Morrison, supra note 48, at 1. Consequently, the USA has engaged in various efforts to slow Chinese growth and foster a trade-war environment.

${ }^{63}$ Allen et al. 2005, at 57. 


\section{Factors Behind Substantial Economic Development in China}

This study identifies the following reasons for the enormous economic growth in China without the conventional concept of judicial independence.

\subsection{Promoting the Rule of Law and Judicial Reforms}

The early submission of the rule of law was advertised in its primary tradition of the political agenda as a shield for human rights, personal liberty, and individual dignity. In modern compliance, however, the oratory of the rule of law is very common in business communications, in the research and publications of the World Bank, the International Monetary Fund, the Asian Development Bank (ADB), in twosided development support projects, and even in U.S.-China diplomatic dialogue. ${ }^{64}$ The rhetoric is that the rule of law is an essential element in economic development, not only in socialist countries, but also in developing capitalistic countries as well. ${ }^{65}$ China has promised to establish a "harmonious society of socialism" with features of the rule of law, justice, and fairness. ${ }^{66}$ After the end of the Cultural Revolution (1966-1976), China put into effect wide-ranging institutional reforms to develop and facilitate economic advancement. At that time, the CCP placed expectations on the judiciary in ensuring the constancy of property and "profits in market-oriented societies." ${ }^{167}$ The basis and background of the CCP's policy highlights that,

The People's Republic of China governs the country according to law and makes it a socialist country under the rule of law. ${ }^{68}$

To fulfill these expectations and policies, in the 1980s China started judicial reforms with the vital objective of founding a state ruled according to the law. ${ }^{69}$ In 1997, the CCP announced a ten-year goal for national social and economic development at the Fifteenth National Congress with a clear policy of "managing state affairs according to the law" and "building a socialist country ruled by law."70

64 John K.M. Ohnesorge, The Rule of Law, Economic Development, and the Developmental States of Northeast Asia in Law Development in East and Southeast Asia 70 (C. Antons (ed.), London: Routledge Curzon, 2003).

65 World Bank Development Report 1996: From Plan to Market (New York: Oxford University Press, 1996) (Dec. 20, 2019), also available at http://documents.worldbank.org/curated/en/917191468155732199/ pdf/158920REPLACEMENTOWDR01996.pdf.

66 Mei Y. Gechlik, Judicial Reform in China: Lessons from Shanghai, 19(1) Columbia Journal of Asian Law 97, 98 (2005).

67 Yanrong 2018.

68 Constitution of the People's Republic of China (1982), Ch. 1, Art. 5.

69 Xin Chunying, What Kind of Judicial Power Does China Need?, 1(1) International Journal of Constitutional Law (2003).

70 Margaret Y.K. Woo, Court Reform with Chinese Characteristics, 27(1) Washington International Law Journal 241, 246 (2017). 
In China, economic development policies are progressively placed into legal form; this is because market reforms are connected to the law and the courts; and because reform was required to build confidence in foreign traders and stakeholders. In the age of universal competition for investment, it is hard to find any state that is not involved in some agenda of judicial reform intended to make legal institutions more efficient, effective, and predictable. ${ }^{11}$ Consequently, China adopted a number of reform initiatives in the legal arena, because legal and judicial reforms were desirable to facilitate economic reform that is required for healthy economic growth. China developed a system that offered foreign investors security and stability. China thus established an arbitration system for commercial disputes involving international parties to secure foreign investment which was constructed on international standards and norms and run by China's International Economic and Trade Arbitration Commission. ${ }^{72}$ In 1994, The Chinese Arbitration Law was approved and circulated.

Prior to 2013 the CCP issued three "Five-year Reform Programs for the People's Courts" in 1999, 2005, and 2009. ${ }^{73}$ The Supreme Peoples' Court (SPC) declared a fiveyear (1999-2003) reform strategy to shape a "fair, open, highly effective, honest, and well-functioning" judicial system. ${ }^{74}$ This reform policy was designed with the aim of rebuilding judicial credibility, reconstruction of a professional judiciary, and improvement of the adjudication process. The measures included introducing single judge trial procedure for higher court efficiency, establishing enforcement offices at all levels of the courts, and requiring a law school degree for new judges. The second fiveyear court reform plan of 2004-2008 was issued in October 2005. This reform plan had the intended targets of ensuring judicial neutrality and fairness, improving judicial credibility, and promoting judicial transparency and professionalism. The concrete measures were: the principle of presumption of innocence recognized and applied in court hearings, and judicial review of administrative decisions. In 2006, around 17,018 administrative decisions were affirmed illegal or invalid. As a result of review, $34 \%$ of the decisions of (the various levels of) the government or its branches underwent changes, and the courts moved forward with only $18 \%$ of the total administrative decisions. An additional result was improved selection and promotional mechanisms for judges. In 2006, around 127 judges from the lower courts were promoted to sit as judges at higher courts, including as justices at the Supreme People's Court. ${ }^{75}$

71 Tamir Moustafa \& Tom Ginsburg, Introduction: The Functions of Courts in Authoritarian Politics in Rule by Law: The Politics of Courts in Authoritarian Regimes, supra note 20, at 1, 9.

72 Woo 2017, at 243.

73 Supreme People's Court of the People's Republic of China, Whitepaper on Judicial Reform of Chinese Courts (2016) (Dec. 20, 2019), available at http://english.court.gov.cn/2016-03/03/content_23724636.htm.

74 Gechlik 2005, at 98.

75 Congressional-Executive Commission on China, Second Five-Year Reform Program for the People's Courts (2004-2008) (CECC Partial Translation) (2006) (Dec. 20, 2019), available at https://www.cecc.gov/resources/ legal-provisions/second-five-year-reform-program-for-the-peoples-courts-2004-2008-cecc. 
The third five-year court reform plan, promulgated in 2009, encompassed the period from 2009 to 2013. This reform plan was formulated to develop "working mechanisms, maintaining social fairness and justice," satisfying prospects of the ordinary people vis-à-vis the work of the judiciary. ${ }^{76}$ The main tasks of judicial reform of the people's courts were: "reform and improve the operating mechanism for the judicial functions," "improve the criminal trial system," and "reform and improve the civil and administrative trial systems."177 This reform phase granted mediation in a campaign promoted by the government to relieve pressure on the courts. Accordingly, in 2012 the civil procedure rules were also modified. ${ }^{78}$ The Fourth Judicial Reform Plan as declared by the SPC covers the period from 2014 to 2019. One of the key aims of this reform policy is the accomplishment of the "Diversified Dispute Resolution Mechanism of reconciliation, mediation, arbitration, notarization, administrative ruling, administrative reconsideration and litigation.".79 The SPC has also tried to establish open and public trial so as to legitimize the work of the courts and transparency. According to the work report of the Supreme People's Court 2014, in 2013 the SPC published about 45,000 trial proceedings on public media including high-profile cases. Also, the SPC established a website to publish court judgment documents. Hitherto, about 3,900 SPC judgments and 1.65 million from local courts had been published. ${ }^{80}$ Also, in 2018 China made several improvements in the judicial system: it launched the Shanghai Financial Court, which is China's first court specializing in the conduct of finance-related cases; and two new internet courts established in Beijing and Guangzhou. Among other actions, the SPC opened two international commercial courts in the cities of Shenzhen and Xi'an and "to promote transparency, over 2 million court trials have been live-streamed online on the SPCrun official website." ${ }^{\prime \prime 1}$ In summary, China's reforms on laws and the judiciary not just set the basis of expectations and representative goals, they also never ignore the fundamental national identity. Scholars contend that all laws and courts are

76 Supreme People's Court of the People's Republic of China, Notice of the Supreme People's Court on Issuing the Third Five-Year Reform Outline for the People's Courts (2009-2013) (Dec. 20, 2019), available at http://www.lawinfochina.com/Law/Display.asp?ld=7380.

77 Id.

78 Woo 2017, at 253-254.

79 Supreme People's Court of the People's Republic of China, Opinions of the Supreme People's Court on People's Courts Further Deepening the Reform of Diversified Dispute Resolution Mechanism (2016) (Dec. 20, 2019), available at http://en.pkulaw.cn/display.aspx?cgid=273230\&lib=law; Woo 2017, at 254.

80 Supreme People's Court of the People's Republic of China, Highlights of Work Report of China's Supreme People's Court (2014) (Dec. 20, 2019), available at http://english.court.gov.cn/2015-07/15/ content_21289597.htm.

81 Supreme People's Court of the People's Republic of China, Highlights of Supreme People's Court Work Report (2019) (Dec. 20, 2019), available at http://english.court.gov.cn/2019-03/12/content_37449108. htm; Highlights of China's Judicial Reform Progress in 2018, Xinhuanet, 15 January 2019 (Dec. 20, 2019), available at http://www.xinhuanet.com/english/2019-01/15/c_137745598.htm. 
a reflection of "national goals and identity." Any proposed reforms that challenge Party goals and national identity fixed by the Party are predestined to fail. ${ }^{82}$

\subsection{Gradual Economic Reforms}

Dani Rodrik sketched an overall conclusion based on a study of the economic growth of some developing countries. He stated,

The onset of economic growth does not require deep and extensive institutional reform

and

Sustaining high growth in the face of adverse circumstances requires ever stronger institutions. ${ }^{83}$

The Chinese leadership understood the reality and necessity of strong institutions; therefore, they made numerous reforms in the institutional financial system to enhance and sustain economic expansion. China adopted several reform initiatives in economic aspects in order to enhance and sustain development. The early Chinese financial reform approaches included the dual-track, the township-village enterprises (TVEs), and fiscal federalism. ${ }^{84}$ They introduced incentives in the market to expand production and to create new, strong firms, "but the new inputs and outputs would be traded in what was a market economy." ${ }^{185}$ China launched market-oriented reforms in six very important fields: fiscal reforms; "reforms in [the] financial sector"; exchange rate reforms; a "market-based macro prudential system"; allowing private investment in "consumption goods markets, capital goods markets," and the financial sector; and renovating the government's functions, and promoting the reform of the legal system. ${ }^{86}$ In 2003, the China Banking Regulatory Commission (CBRC) was established to take possession of the regulatory and supervisory responsibilities for the banking sector from the People's Bank of China (PBC). ${ }^{87}$

82 Woo 2017, at 242.

83 Dani Rodrik, Introduction: What Do We Learn from Country Narratives? in In Search of Prosperity: Analytic Narratives on Economic Growth 1, 15-16 (D. Rodrik (ed.), Princeton: Princeton University Press, 2003). Jinglian Wu, Understanding and Interpreting Chinese Economic Reform (Mason, $\mathrm{OH}$ : Thomson/SouthWestern, 2005).

85 Dam 2007, at 271.

86 Yang, supra note 54 , at 4.

87 China's Growth and Integration into the World Economy: Prospects and Challenges, International Monetary Fund, Occasional Paper 232 (2004), at 47 https://www.imf.org/external/pubs/ft/op/232/ op232.pdf. 
The gradual opening-up policy has played a crucial role in promoting and developing the private sector and has contributed to economic growth. Scholars remark that the private sector has increased much quicker than others despite comparatively poorer regular financing channels and legal protection, but effective, alternativefinancing paths and corporate governance techniques exist to support the progression of the private sector. ${ }^{88}$ China is making the transformation from tentative policy to deep and widespread institutional policy measures. Accordingly, China's entrance into the World Trade Organization (WTO) in 2001 can be seen as a milestone. This step was part of a trade reform policy. The trade reforms and accession into WTO have been essential in promoting China's economic expansion and supporting incorporation into the global trading system.

The slogan "Made in China 2025" stands as one more crucial item on the agenda to the new goal of economic growth through "innovation." In 2015, the Chinese government announced a plan identifying innovation as a top priority under its economic planning with the launch of a number of important initiatives. The goal of the "Made in China" plan is to modernize and upgrade China's ten key manufacturing sectors through widespread government assistance in order to make China a key global actor in these sectors. ${ }^{89}$ In this regard, U.S. trade representative Robert Lighthizer designated the "Made in China 2025" inventiveness as "a very, very serious challenge, not just to us, but to Europe, Japan, and the global trading system..$^{190}$ The Belt and Road Initiative (BRI), also called "One Belt, One Road" (OBOR), is one more new effort by China to expand its economic growth and power globally. U.S. policymakers and analysts are cognizant of it and consider it to be another area of concern. They contend that China could make use of this initiative to boost its industries, expand new foreign markets, "influence other countries to adopt China's economic model; and expand China's 'soft power"' in the various countries that participate in the initiative. ${ }^{91}$ The effectiveness of reforms in the economic and financial sectors are well recognized. One report prepared by the U.S. Congressional research service noted that before the commencement of economic reformations and trade liberalization,

China maintained policies that kept the economy very poor, stagnant, centrally controlled, vastly inefficient, and relatively isolated from the global economy.

\footnotetext{
${ }^{88}$ Allen et al. 2005, at 59.

89 Morrison, supra note 48.

90 Id.

91 Id. at 2 .
} 
Since adopting free-market reforms and opening up to foreign investment and trade, China has become one of the world's fastest-growing economies, with real annual GDP growing at the average annual rate of $9.5 \%$ through $2017 . .^{92}$

\subsection{Maintaining Adjudicative Independence}

The enforcement of substantive law is more important than its content, and the judiciary is a focal institution for substantive law's enforcement. The proper enforcement of law concerns an efficient judicial system, the quality of judges and the judiciary, and the judiciary's relation to the other branches of government. From the rule of law standpoint, both in implementing the law and in managing "the problem of the predatory state," the connection of the judiciary to other divisions of the government is essential. ${ }^{93}$ Subsequently, judicial independence from the rest of the government branches is not only of fundamental significance but also a substance of outside assistance from international financial institutions, particularly in developing and third-world countries. However, the context of understanding and maintaining judicial independence is varied and based on a number of principles and standards. Impartial adjudication, independent adjudication or "adjudicative independence" is also generally agreed on a standard of judicial independence. Adjudicative independence as the perspective of judicial independence is mostly maintained in the courts of Great Britain and other European countries. ${ }^{94}$

China stands on adjudicative independence in the matter of maintaining judicial independence. The basis of adjudicative independence in China is Article 126 of the Constitution of China, which states,

The people's courts exercise judicial power independently, following the provisions of law and not subject to interference by any administrative organ, public organization or individual. ${ }^{95}$

Some Chinese scholars refer precisely to the term "adjudicative independence," and demonstrate it as the unique feature of judicial independence in China. ${ }^{96} \mathrm{For}$ the moment, many international scholars contend adjudicative independence chiefly

\footnotetext{
92 Morrison, supra note 2.

93 Dam 2007, at 228.

94 Yanrong 2018.

95 Constitution of the People's Republic of China (1982), Art. 126.

96 MingZhao,从历史的深处走来-漫议转型时期的当代中国政治与司法改革[Coming from History-OnRelationship of China's Judicial System Reform and Political System Reform], 3 政法论丛 [Journal of Political Science and Law] 3 (2008); Guangzhong Chen, The Principle of Judicial Independence with Chinese Characteristics from the Perspective of Comparative Law, 27(11) Chinese Prosecutor 1 (2013); Yanrong 2018.
} 
by denoting it to judicial independence. ${ }^{97}$ The ultimate factor to enhance economic development is an independent adjudication system, not the method of country regime, whether autocracy or authoritarian or democracy. China proves this position where Western scholars randomly claim that China lacks judicial independence. China does not bear the conventional concept of judicial independence, but emphasizes adjudicative independence and the rule of law.

\subsection{Facilitating Trade and Investment}

Long-term economic growth not only depends on foreign direct investment but also on the formation of new domestic enterprises backed by local savings. ${ }^{98}$ Strong and worthy financial regulations concerning credit markets, shareholder rights, creditors rights, contract enforcement, and protection of property rights are vital to facilitate trade and investment. Making sound substantive law, providing a smooth and efficient procedure to run business, promoting infrastructure, protecting foreign investment, and securing minority investors are ways of advancing business and investment. China properly stimulates all factors to make it easy to do business in the country. According to the World Bank Doing Business rankings for 2019 (Table 4), China is $46^{\text {th }}$ out of the 190 economies ranked. China is also among the top ten countries recognized for their improvement (over past performance), and the only economy so recognized in East Asia and the Pacific region. In this report, China's ranking in the factor "Starting a Business" is $28^{\text {th }} .99$ The factor "Enforcing Contracts" measures the performance of the judiciary in the event of a contract lawsuit between the state and a private party, and between private parties. Adjudicative independence or independent judiciary is most essential for good performance of contract enforcement. The World Bank ranks China $6^{\text {th }}$ in contract enforcement among the 190 countries. In China, land registration or the system of registering property is exceptionally strong, and procedures are also efficient. ${ }^{100}$ In the same report, in the factor "Registering Property" China is ranked $27^{\text {th }}$.

Table 4: The World Bank Doing Business (WBDB) 2019 ranking of China in various factors relating to ease of doing business

\begin{tabular}{|c|c|c|c|}
\hline Factors & WBDB 2019 Rank & WBDB 2019 Score & WBDB 2018 Score \\
\hline Starting a Business & 28 & 93.52 & 85.47 \\
\hline
\end{tabular}

97 Peerenboom 2009.

98 Dam 2007, at 102.

99 A detailed description about China in the World Bank Doing Business can be found online (Dec. 20, 2019), available at https://www.doingbusiness.org/en/data/exploreeconomies/china. 


\begin{tabular}{|c|c|c|c|}
\hline Getting Electricity & 14 & 92.01 & 65.71 \\
\hline $\begin{array}{c}\text { Registering } \\
\text { Property }\end{array}$ & 27 & 80.80 & 74.99 \\
\hline $\begin{array}{c}\text { Protecting } \\
\text { Minority Investors }\end{array}$ & 64 & 60.00 & 55.00 \\
\hline Paying Taxes & 114 & 67.53 & 62.90 \\
\hline $\begin{array}{c}\text { Enforcing } \\
\text { Contracts }\end{array}$ & 6 & 78.97 & 78.97 \\
\hline $\begin{array}{c}\text { Resolving } \\
\text { Insolvency }\end{array}$ & 61 & 55.82 & 55.82 \\
\hline
\end{tabular}

Source: World Bank Doing Business ranking report 2019

Overall, China's ranking $\left(46^{\text {th }}\right)$ is higher than the other countries in both the South Asian and the East Asian regions, although lower than the average of member countries of the Organisation for Economic Co-operation and Development (OECD). In fact, China is not a member of the OECD. Table 4 above shows that in 2019 in all factors, with the exception of "Enforcing Contracts" and "Resolving Insolvency," China scored higher than in 2018.

From the several World Bank Doing Business reports it is apparent that China's initiatives to facilitate business and trade are noteworthy. In the last decade, China has demonstrated remarkable reform agendas among numerous factors to promote trade. The reforms have taken place in respect of starting a business, dealing with construction permits, getting electricity, contract enforcement, registering property, protecting minority investors, paying taxes, cross-border trade, among others. The government carefully designs reform approaches aimed at developing the business regulatory environment to make it easier to do business. For instance, to attain that targeted objective, between January 2012 and December 2014 China exempted small and micro enterprises from paying various administrative fees to start a business so as to lower the expense of doing so. The reforms to enhance the efficiency of the business process cover introducing a single form to attain an organization code, tax registration, and business license. Also, the reforms launched an online company registration system and simplified social security registration in Beijing and Shanghai. In these two great cities, in order to start a new business, an entrepreneur obtains company registration and a business license within "five days" - and with no charges from the State Administration of Industry and Commerce (SAIC). ${ }^{101}$

The government has undertaken several initiatives that has meaningfully reduced the time needed to get an electricity connection for business. In the first half of

101 The World Bank Doing Business 2019; China Economy Profile 2019 (Dec. 20, 2019), available at https:// www.indexmundi.com/china/economy_profile.html. 
2018, the government introduced a reform to the construction permit procedure. The reform covers "simplified documentation requirements, improved processing times, and expanded public access to information." To simplify cross-border trade, China applied "a national trade single window" connecting the tax and customs administrations, the Ministry of Commerce, port authorities, and other agencies engaged in import and export procedures ${ }^{102}$ Security of property rights facilitates trade and investment in the market; for this purpose, China strongly ensures adequate protection of property rights and punishment for violations of these rights. The government ensures that policies are credible and not harmful to capital expenditures and investment by enacting reliable regulations that signal stability and certainty to the market.

\subsection{Crackdown Against Corruption}

The presence of corruption in the public and private sectors is a substantial threat to high economic development, and even possibly a cause of poverty. ${ }^{103}$ Corruption is perhaps the most significant factor hindering economic growth in a number of countries, ${ }^{104}$ and the reason for loss of stockholder confidence. ${ }^{105}$ The Chinese leadership has vowed to prevent corruption in all sectors to promote sound economic development. Accordingly, from 1998 to 2004, around 8,000 judges and other court personnel were penalized for violating procedures or laws. This amounts to approximately $2.7 \%$ of China's judicial staff. ${ }^{106}$ In 2013, about 381 judges and court employees were denounced for misusing their power and violating laws and procedures, 101 of whom were prosecuted. ${ }^{107}$ According to work report 2013 to 2017 of the Supreme People's Court, the Court punished 53 staff members for violating Party disciplinary rules and laws. Moreover, about 3,338 judicial members at local courts countrywide were denounced for misusing their authority, 531 of whom were prosecuted. In the same report, the SPC declared their stand on corruption with the language,

The SPC would discipline judges and court staff more strictly and uphold a zero-tolerance policy on corruption. ${ }^{108}$

\footnotetext{
102 The World Bank Doing Business 2019, at 12.

103 Mohammad Saiful Islam, Is the Independent Judiciary Important in Bangladesh? A Legal and Economic Study, 5(3) International Journal of Law 38, 45 (2019). Supreme People's Court of the People's Republic of China, Highlights of Supreme People's Court Work Report (2018).
} 
In 2018, China undertook even more serious action against judicial corruption: around 1,064 court employees of Chinese courts at all levels were investigated and punished for abusing the judicial and enforcement authority. Also, about 369 court employees were investigated and punished for their "behaviors against the spirit of the eight-point regulation on improving Party and government conduct" mentioned in the SPC work report 2018. ${ }^{109}$ The exact punishment for corruption among violators is unknown; maximum official document references to "violations of law and discipline" in the courts are set in the circumstance of corruption. This mention undoubtedly indicates that a great number of violators have been penalized for corruption. ${ }^{110}$

The Chinese government has embraced a robust position against corruption not only in judicial and administrative sectors, but also at all levels. The process of controlling (eliminating) corruption outside the judiciary is conducted and punished properly through judicial trial. In 2018, all levels of Chinese courts concluded 28,000 graft cases concerning bribery, embezzlement, and negligence of duty. These cases linked 33,000 people with 18 past officials at the provincial level and above. A total of 2,466 persons involved in bribery were sentenced in the heavy crackdown on such crime. ${ }^{111}$ A recent momentous incident relating to the anti-corruption crackdown regarded the prosecution of Meng Hongwei, former Interpol chief and formerly one of six vice-ministers in China's Public Security Ministry, for allegedly taking bribes. The charges put forward regard abusing his position for private gain, mishandling state funds for his family's exorbitant lifestyle, and violating Party principles. According to the Central Commission for Discipline Inspection (CCDI), these charges amount to a "serious violation of law and discipline." Moreover, Lu Wei, China's former Chief of Internet Censorship, was penalized to fourteen years imprisonment for bribery in 2019. ${ }^{12}$

\section{Conclusion}

An impartial adjudication system is highly appraised as necessary in ensuring the rights of the public and private citizens, and in building a just society by eradicating unfairness and injustice. Today, it is also measured as a mode of attraction to foreign investment, to business, and to the sustainment of economic growth. The literature on development policy argues that a better quality judicial and legal system, and

109 Supreme People's Court of the People's Republic of China, Highlights of Supreme People's Court Work Report (2019).

110 Gechlik 2005, at 129.

111 Supreme People's Court of the People's Republic of China, Highlights of Supreme People's Court Work Report (2019).

112 Meng Hongwei: China to Prosecute Former Interpol Chief, BBC News, 27 March 2019 (Dec. 20, 2019), available at https://www.bbc.com/news/world-asia-china-47718827. 
reforms in contract law and property rights protection, can generate economic growth in a country. Western jurists and political scientists claim that China operates by a one-party authoritarian regime, and that there is no independent and impartial judicial system. Yet, China is a unique example of the fastest economic development in the world.

In keeping with the above discussion, it is evident that an independent adjudication system to promote contract enforcement and attract international investment is feasible in a one-party regime. Despite huge Western blame vis-à-vis its weak and non-independent judicial system, China has achieved very impressive economic development. This is because, regardless of the enormous deficiencies of the legal system of China, the progressive movement is distinctive: the Party widely implements reform as a part of its public commitment to remodeling the legal system and building more independent legal and judicial institutions. ${ }^{1{ }^{13}} \mathrm{China}$ has made market-oriented reforms in the legal system that have strengthened the effort to safeguard property rights, encourage trade, and attract investment. ${ }^{114}$ Moreover, China facilitates trade and doing business through the enactment of new regulations, and the amendment of already existing regulations, that make it easier to do business in the country. And while China does not maintain the conventional concept of judicial independence, it does assert a new and unique concept of an independent judicial system which is termed "adjudicative independence" or "independent and impartial adjudication."

China's experience may be regarded as the instructions for other developing and third-world countries with a weak legal system and emerging financial markets.

\section{References}

Allen F. et al. Law, Finance, and Economic Growth in China, 77(1) Journal of Financial Economics 57 (2005). https://doi.org/10.1016/j.jineco.2004.06.010

Buscaglia E. \& Dakolias M. An Analysis of the Causes of Corruption in the Judiciary, 30 Law and Policy in International Business 95 (1999).

Chan P.C.H. An Uphill Battle: How China's Obsession with Social Stability Is Blocking Judicial Reform, 100(3) Judicature 14 (2016).

Chavez R.B. The Rule of Law and Courts in Democratizing Regimes in The Oxford Handbook of Law and Politics 63 (K.E. Whittington et al. (eds.), New York: Oxford University Press, 2008). https://doi.org/10.1093/oxfordhb/9780199208425.003.0005

Chen G. The Principle of Judicial Independence with Chinese Characteristics from the Perspective of Comparative Law, 27(11) Chinese Prosecutor 1 (2013).

Chen J. Chinese Law: Towards an Understanding of Chinese Law, Its Nature, and Development (The Hague; Boston: Martinus Nijhoff Publishers, 1999).

\footnotetext{
113 Peerenboom 2002.

114 Id.
} 
Chunying X. What Kind of Judicial Power Does China Need?, 1(1) International Journal of Constitutional Law 58 (2003). https://doi.org/10.1093/icon/1.1.58

Cohen J.A. The Chinese Communist Party and "Judicial Independence": 1949-1959, 82(5) Harvard Law Review 967 (1969). https://doi.org/10.2307/1339545

Dam K.W. The Law-Growth Nexus: The Rule of Law and Economic Development (Washington, D.C.: Brookings Institution Press, 2007).

Fairbairn W. An Examination of Judicial Independence in China, 23(4) Journal of Financial Crime 819 (2016). https://doi.org/10.1108/jfc-12-2015-0068

Ferejohn J. Independent Judges, Dependent Judiciary: Explaining Judicial Independence, 72(2-3) Southern California Law Review 353 (1999).

Gallagher M.E. Use the Law as Your Weapon! The Rule of Law and Labor Conflict in the PRC in Engaging the Law in China: State, Society, and Possibilities for Justice 54 (N.J. Diamant et al. (eds.), Stanford: Stanford University Press, 2005).

Gechlik M.Y. Judicial Reform in China: Lessons from Shanghai, 19(1) Columbia Journal of Asian Law 97 (2005).

Gibson J.L. "New-Style" Judicial Campaigns and the Legitimacy of State High Courts, 71(4) Journal of Politics 1285 (2009). https://doi.org/10.1017/s0022381609990211

Hailsham L. The Independence of the Judicial Process, 13(1) Israel Law Review 1 (1978). https://doi.org/10.1017/s0021223700006087

Hamilton A. Federalist No. 78 in Hamilton A. et al. The Federalist Papers 235 (New York: Palgrave Macmillan, 2009). https://doi.org/10.1057/9780230102019_47

He X. Ideology or Reality?: Limited Judicial Independence in Contemporary Rural China, 6(3) Australian Journal of Asian Law 213 (2004).

He X. The Politics of Courts in China, 2(2) China Law and Society Review 129 (2017). https://doi.org/10.1163/25427466-0020001

Hung V.M.-Y. China's WTO Commitment on Independent Judicial Review: Impact on Legal and Political Reform, 52(1) American Journal of Comparative Law 77 (2004). https://doi.org/10.2307/4144447

Islam M.S. Independent Judiciary: Nature and Facets from the International Context, 6(2) International Journal of Ethics in Social Sciences 15 (2018).

Islam M.S. Is the Independent Judiciary Important in Bangladesh? A Legal and Economic Study, 5(3) International Journal of Law 38 (2019).

Judicial Independence: The Contemporary Debate (S. Shetreet \& J. Deschênes (eds.), Dordrecht; Boston; Lancaster: Martinus Nijhoff Publishers, 1985).

Landry P. The Institutional Diffusion of Courts in China: Evidence from Survey Data in Rule by Law: The Politics of Courts in Authoritarian Regimes 207 (T. Ginsburg \& T. Moustafa (eds.), New York: Cambridge University Press, 2008). https://doi.org/10.1017/ cbo9780511814822.009

Larkins C.M. Judicial Independence and Democratization: A Theoretical and Conceptual Analysis, 44(4) American Journal of Comparative Law 605 (1996). https:// doi.org/10.2307/840623 
Li Y. Judicial Independence in China: An Attainable Principle? (The Hague: Eleven International Publishing, 2013).

Moustafa T. \& Ginsburg T. Introduction: The Functions of Courts in Authoritarian Politics in Rule by Law: The Politics of Courts in Authoritarian Regimes 1 (T. Ginsburg \& T. Moustafa (eds.), New York: Cambridge University Press, 2008). https://doi.org/ 10.1017/cbo9780511814822.001

Ohnesorge J.K.M. The Rule of Law, Economic Development, and the Developmental States of Northeast Asia in Law Development in East and Southeast Asia 70 (C. Antons (ed.), London: Routledge Curzon, 2003). https://doi.org/10.2139/ssrn.3480823

Peerenboom R. China's Long March Toward Rule of Law (Cambrige and New York: Cambridge University Press, 2002). https://doi.org/10.1017/cbo9780511493737

Peerenboom R. Judicial Independence in China: Common Myths and Unfounded Assumptions in Judicial Independence in China: Lessons for Global Rule of Law Promotion 69 (R. Peerenboom (ed.), New York: Cambridge University Press, 2009). https://doi. org/10.1017/cbo9780511809484.005

Rodrik D. Introduction: What Do We Learn from Country Narratives? in In Search of Prosperity: Analytic Narratives on Economic Growth 1 (D. Rodrik (ed.), Princeton: Princeton University Press, 2003). https://doi.org/10.1515/9781400845897-003

Salzberger E.M. A Positive Analysis of the Doctrine of Separation of Powers, or: Why Do We Have an Independent Judiciary?, 13(4) International Review of Law Economics 349 (1993). https://doi.org/10.1016/0144-8188(93)90029-5

Shetreet S. Creating a Culture of Judicial Independence: The Practical Challenge and the Conceptual and Constitutional Infrastructure in The Culture of Judicial Independence: Conceptual Foundations and Practical Challenges 15 (S. Shetreet \& C. Forsyth (eds.), Leiden: Martinus Nijhoff Publisher, 2012). https://doi.org/10.1163/ej.9789004188334.i639.17

Shetreet S.Judicial Independence and Accountability:Core Values in LiberalDemocracies in Judiciaries in Comparative Perspective 3 (H.P. Lee (ed.), New York: Cambridge University Press, 2011). https://doi.org/10.1017/cbo9780511996399.003

Shetreet S. Judicial Independence: New Conceptual Dimensions and Contemporary Challenges in Judicial Independence: The Contemporary Debate 590 (S. Shetreet \& J. Deschênes (eds.), Dordrecht; Boston; Lancaster: Martinus Nijhoff Publishers, 1985).

Woo M.Y.K. Court Reform with Chinese Characteristics, 27(1) Washington International Law Journal 241 (2017).

World Development Report 2005: A Better Investment Climate for Everyone (New York: The World Bank and Oxford University Press, 2004). https://doi.org/10.1596/0-82135682-8

Wu J.Understanding and Interpreting Chinese Economic Reform (Mason, $\mathrm{OH}$ :Thomson/ South-Western, 2005).

Yanrong Z. The Way to Understand the Nature and Extent of Judicial Independence in China, 6(01) Asian Journal of Law and Society 131 (2018). https://doi.org/10.1017/als. 2018.27 
Zhao M. 从历史的深处走来 - 漫议转型时期的当代中国政治与司法改革[Coming from History - On Relationship of China's Judicial System Reform and Political System Reform], 3 政法论丛 [Journal of Political Science and Law] 3 (2008).

Zhao Y. The Expansion of Judicial Power in China (New Haven: Yale University Press, 2003).

Zhiwei T. Perfecting the Constitutional Provision on Independent Adjudication and Ancillary Reform, 6 Jianghai Academic Journal 109 (2005).

\section{Information about the authors}

Mohammad Saiful Islam (Kumira, Bangladesh) - Assistant Professor, Department of Law, International Islamic University Chittagong (Kumira, 4318, Bangladesh; e-mail: saiful@law.iiuc.ac.bd).

Xu Xin (Beijing, China) - Professor, School of Law, Beijing Institute of Technology (5 Zhongguancun St., Haidian, Beijing, 100811, China; e-mail: xuxin.net@163.com). 